\title{
Students' Perception at the Use of Padlet in Linguistics Class
}

\author{
Choiril Anwar*; Kurniawan Yudhi Nugroho; Idha Nurhamidah
}

\author{
Language and Communication Science Faculty \\ Universitas Islam Sultan Agung, Semarang, Indonesia
}

*Corresponding Author

Email: choirilanwar@unissula.ac.id

\begin{tabular}{|c|c|}
\hline Article Info & ABSTRACT \\
\hline $\begin{array}{l}\text { Article History } \\
\text { - Article Received } \\
15^{\text {th }} \text { March } 2019 \\
\text { - Article Reviewed } \\
20^{\text {th }} \text { March } 2019 \\
\text { - Article Accepted } \\
11^{\text {th }} \text { April } 2019 \\
\text { Keywords } \\
\text { Padlet } \\
\text { linguistics class } \\
\text { students' perception }\end{array}$ & $\begin{array}{l}\text { This study aims at investigating students' perceptions of the use of Padlet in the class } \\
\text { of Introduction to Functional Linguistics. The population of this study was a class } \\
\text { of } 2014 \text { batch student of English Language Education program at Sultan Agung } \\
\text { Islamic University (UNISSULA) Semarang with a sample of } 28 \text { people. This } \\
\text { research is in the form of qualitative descriptive design. The data collection method } \\
\text { uses observations and questionnaire. The data is then analyzed using interpretive } \\
\text { descriptive analysis. The specific target to be achieved in this study is that by } \\
\text { knowing students' perceptions of the use of Padlet, then this result can be used as a } \\
\text { reference for the Faculty of Language and Communication Science and other } \\
\text { faculties in the UNISSULA environment to improve the performance and quality } \\
\text { of service to students especially in the learning and teaching process. In addition, the } \\
\text { results of this study can also be a reference for both the Study Program and the } \\
\text { Faculty to review the curriculum that has been implemented so far. From the data } \\
\text { obtained through questionnaires distributed to } 28 \text { students of the English Language } \\
\text { Education Study Program at the Faculty of Languages and Communication Science } \\
\text { of Sultan Agung Islamic University Semarang in the class of } 2014 / 2015 \text {, researchers } \\
\text { can conclude that these students have very diverse perceptions in the use of Padlet } \\
\text { media in learning Introduction to Functional Linguistics. To be sure, most students } \\
\text { really positively appreciate the use of this media in linguistic learning in general. }\end{array}$ \\
\hline
\end{tabular}

\section{INTRODUCTION}

It is important for students to understand the subjects they are studying in one semester. Of the courses that are followed, inevitably, there are types of subjects that are classified as preferred and also there are courses that tend to be disliked by students in general.

Among several elective courses, there is one subject that is considered difficult for most students of English Language Education Program at the Faculty of Language and Communication Science of Sultan Agung Islamic University (UNISSULA)
Semarang. The course is Introduction to Functional Linguistics. This course is a continuation of the Introduction to General Linguistics subject.

Introduction to Functional Linguistics contains basic theories in Functional Linguistics. These theories include genres, grammar, text, context, mood, transitivity, clauses, themes, rheme, and cohesion. The many terms that are scattered in this course generally make students reluctant to learn more deeply so that these subjects tend to be unpopular in their eyes.

The students reasoned that, in addition to students having to memorize complicated terms in language, 
they were also required to know the formulas and functions of these complicated terms in a text. Therefore, we need a method or technique or media that can be used by teachers to make students easy to understand the material from the class, especially in this case the class Introduction to Functional Linguistics. Actually there are many media that can be accessed online by students in learning and teaching. One of them is Padlet.

Padlet is a useful device-agnostic tool for interaction on virtual wall that allows people to express their thoughts on a common topic easily and can be used for simple or even complicated instructional tasks among experts [1][2][3]. It works like an online paper sheet in which people can post any contents (e.g. images, videos, documents, texts) anywhere on the page, together with anyone, and can be accessed from many devices such as laptop, PC, tablet, or smartphone[2]. Using Padlet in learning process allows the availability of pleasant spaces for learners to carry out collaborative classroom activities[4]. With features that are attractive and futuristic and easy to use by users[5], Padlet is then believed to make it easier for students to understand the material in the class of Introduction to Functional Linguistics. Padlet is a virtual and online "bulletin" board, where students and teachers can collaborate, interact, reflect, share various networks (links) and images, in a safe place. Padlet makes it easy for users to create hidden walls with the desired type of URL. Padlet customers can also moderate and delete posts and can adjust their appearance.

Furthermore, Mallon \& Bernsten[5] explained that the features and variety of displays of attractive backgrounds in Padlet provide a variety of user spaces to collaborate at the same time in different places. They can write, draw, chat or talk with other users and even they can enter work to be assessed or sent to other users after that.

It can be concluded shortly that Padlet is an online media in the form of a wall (wall) that is safe and pleasant for its users to be able to interact, collaborate to share writing, images, and other necessities - not least for learning and teaching between teachers and learners.

\section{LITERATURE REVIEW}

\section{a. Padlet Use Mechanism}

Actually there are two ways of operating Padlet: by using the padlet official website[12] and by using the application at android and ios. To use Padlet visa website, thes first thing someone needs to do is to open web page. After the webpage opens, we can click on "Create Something". Well, the Padlet wall is ready to use. However, we need to make modifications related to the main purpose of making the new Padlet. Such modifications can be in the form of making titles, changing background images or display themes according to the topic, making unique and interesting web address names, changing display material loading or selecting Padlet privacy levels that we make[4]. The next step is by using its application. To do so, you can operate it by downloading the application first through android or ios app devices.

In short, Padlet is easy to make and not complicated to use. Next is how smart and creative someone is in utilizing the existing features to be an interesting thematic display so that users or other contributors feel moved to respond to questions or statements from Padlet makers

\section{b. Use of Padlets in Teaching}

In the teaching and learning process, students can use our Padlet wall by opening the web address that we have created before. Students can also open their Padlets using Android or their Smartphones because the Padlet application can be installed easily with a gadget.

After the web is open, students can double-click the Padlet box then write something, take or load pictures or audios or videos, copy links, enter documents etc. Padlet usage interactions occur in real time. That is, the teacher or student can find out when someone else is adding something to the Padlet box. To note that to use Padlet made by teachers, students do not have to have an account on Padlet[4].

Thus it can be said that the use of Padlet in teaching can make it easier for teachers to know the ability or courage of students in responding to certain topics raised by the teacher. By using Padlet, the teacher can also find out the extent to which students understand the material presented previously. Indeed, the risk is that students can see the responses of other students, allowing them to simply copy their friends' answers. So this is where the clever man overcomes this kind of situation. The teacher can emphasize by ensuring 


\section{netIon}

that each response must be different so that at least it can minimize the occurrence of plagiarism behavior.

The use of Padlet in teaching was reviewed by Fuchs[4] in a scientific article entitled "The Writing on the Wall: Using Padlet for Whole-Class Engagement". In his paper, his findings stated that to interact and increase student involvement in the teaching process, teachers can use Padlet as an attractive alternative so that students can be more active in the teaching process.

Another related research was done by Weller[3] entitled "The use of Web 2.0 technology for preservice teacher learning in science education". In the study, secondary school science teachers were given two tasks using online Web 2.0 applications. The results of their work and comments about the use of the technology were evaluated.

Other relevant advanced studies were also conducted by Deni \& Zainal[6] focusing on the use of Padlet in improving communication skills, Lestari[7] underlining Padlet's use in enhancing non-English department students' writing skill, and by Haris, Yanus, and Badusah[8] who investigates the effectiveness of Padlet in ESL Classroom.

The researchers found that there were things that had not been specifically discussed in the second study. The first study focused more on the general picture of using Padlet in the teaching and learning process. The second study is more on the use of Web 2.0 technology in teaching, especially teaching science subjects. While other studies are on improving students' speaking and writing skill and the last was an experimental study of using Padlet in ESL classroom. However, the researchers found something that had not been discussed more and continued from those researches. For example, what is the description of using Padlet in the teaching process in complicated or unpopular subjects or courses for students: Whether it works or not. Then what about the students' comments on this matter. Therefore, researchers feel the need to study this, especially in the subject related to linguistics such as Introduction to Functional Linguistics.

Based on the facts and some varios literatures above, the researchers then tried to conduct a research by trying to explore how students perceive Padlet use in the class Introduction to Functional Linguistics. From the background above, the researchers then formulated the research problems as follows: "What is the perception of students towards the use of Padlet in the class Introduction to Functional Linguistics?" This study then aims to find out the answer on how students' perceptions of the use of Padlet in Introductiion to Functional Linguistics class are.

The following image is a brief overview of the Padlet view that contains questions from the teacher and responses from students.

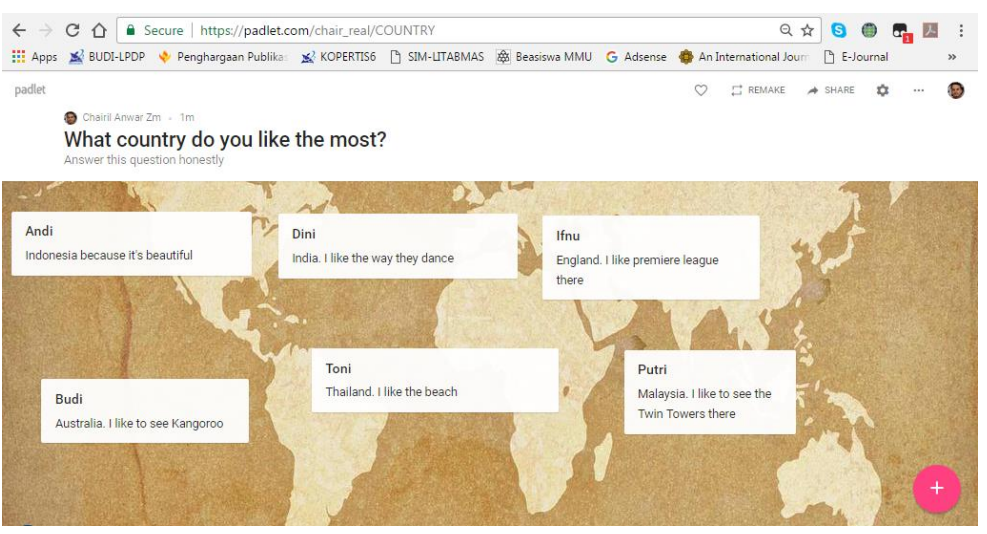

Picture 1. An Example of teacher's question and students's responses in Padlet.

This research has a very high level of significance to be implemented, considering that in terms of contributions both theoretically and practically it is very urgent for various parties, for example for students, lecturers and institutions themselves.

For lecturers, the results of this study will inspire the use of Padlet in the classes it provides. Students will experience new experiences in the learning process of Introduction to Functional Linguistics, something new from the learning process they have experienced so far. As for institutions, the results of this study will spur institutions to improve the quality of teaching and learning services, for example by facilitating and expanding internet access for students.

\section{METHODOLOGY}

This research was conducted through the following stages: First, the researchers observed the research subjects; Second, the researchers prepared for data collection by making a feasibility study of research samples and needs assessment; Third, the researchers collected the data; Fourth, the researchers conducted data analysis; Fifth, the researchers processed data; Sixth, the researchers made interpretations and conclusions; Seventh, the researchers wrote a research report; Eighth, the researchers submitted the research report. 
This research was conducted at the Faculty of Language and Communication Sciences Sultan Agung Islamic University (UNISSULA) Semarang. This type of research is qualitative descriptive research. According to Arikunto[13], qualitative descriptive research is research that describes or explains an event. In addition, this research describes the conditions and research process in detail. Moreover, Best[9] also argues that descriptive qualitative studies are made to describe the characteristics of existing phenomena, developing opinions, ongoing processes, significant impacts, or trends that are in excitement in society.

In short, descriptive qualitative research methods are used to analyze and describe the things that are the object of research. In this study, the things that would be described and explained by the researchers are the perceptions of the students on the use of padlets in classrooms Introduction to Functional Linguistics.

The population in this study was all students of class 2014 study program of English Language Education Faculty of Language and Communication Sciences Sultan Agung Islamic University (UNISSULA). While the research sample was taken from all students who were enrolled in the Introduction to Functional Linguistics class namely 28 persons. The sampling technique used was convenience sampling. According to Dörnyei[10], convenience sampling is a sampling method from researchers. Meanwhile, Crossman[11] states that in convenience sampling researchers use the closest and most existing research subjects to be included in the study.

In this study, data was collected using a questionnaire from Google Form which contained students' perceptions of using Padlet in class courses Introduction to Functional Linguistics. While the data analysis method used in this study was descriptive qualitative. Data in the form of answers from questionnaires about students' perceptions of using Padlet in the Introduction to Functional Linguistics class will be analyzed using a descriptive analysis. After being analyzed, the interpretation of the researchers from the results of the questionnaire will be confirmed (confirmibility) to the respondents whether it is in accordance with their answers or not.

\section{RESULT AND DISCUSSION}

The questionnaire made in the form of online using Google Form emphasizes the question on the respondent's personal data and, subsequently, primarily on knowledge and perception of the subject in the process of learning and teaching the subjects Introduction to Functional Linguistics.

Of the total 28 respondents in this study, there were four male student respondents. The rest (24 people) are female students. All respondents (28 people) are students from one study program, namely English Language Education, Faculty of Language and Communication, Sultan Agung Islamic University, Semarang, the fifth semester of batch 2014.

Before referring to the main discussion in this study, researchers first tried to find out the extent of students' knowledge about Padlet. Here are the respondents' responses in Bahasa.

Situs yang bisa menampilkan foto maupun teks dalam suatu (2)
Padlet adalah suatu media elekteonik yang biasanya digunakan untuk berbagi informasi dalam sebuah group
Mini sharing blog
Padlet adalah website dimana saya bisa menulis pendapat saya tentang pertanyaan2 seputar introduction of
functional linguistic
Suatu aplikasi yang biasa di gunakan untuk men share atau menulis apa yg mau kita tulis,
Padlet adalah sebuah media yang dibuat dan dikemas untuk membantu pengajaran didalam bentuk teks, foto,
tautan dan lainnya.
Padlet adalah suatu website yang yang dapat digunakan oleh seorang guru dalam pengajaran terutama untuk
pengumpulan tugas.
Padlet adalah beranda untuk mengisi materi yg sudah di ajarkan
website Online yang dapat digunakan sebagai sarana diskusi dan mengemukakan gagasan dalam bentuk
tulisan ataupun gambar.
Padlet adalah salah satu cara (tempat) untuk mengirim tugas
Padlet adalah media elektronik ( internet )yang digunakan untuk menuliskan sesuatu.
Padlet adalah branda untuk mengisi materi yang sudah diajarkan
Situs untuk berdiskusi
Padlet adalah tempat untuk mengupload tugas
Padlet adalah sebuah web yang di gunkan untuk menerima dan memberi informasi kedapa orang lain
Sarana untuk belajar bersama dan menuangkan pendapat mengenai materi perkuliahan
Salah satu media untuk mengirim tugas dan membahas materi bersama
Media berbagi gagasan bersama
Beranda dalam situs internet untuk mengeshare opini.
pembahasasan.




\section{netIon}

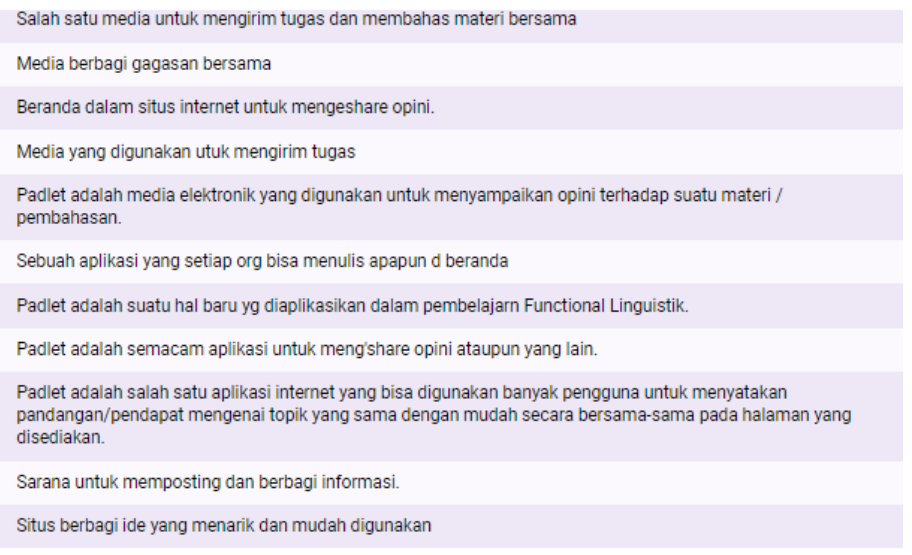

Picture 2. Respondents' Insight on Padlet

Students have diverse knowledge about Padlet. From the overall answers from the respondents, conclusions can be drawn or a summary as follows: The students define Padlet as an electronic medium, application or website created to express opinions, upload or collect assignments, discuss, give and receive information, share ideas, and can also be used to help the teaching process in the form of text, photos, links and more.

Most students of batch 2014/2015 of English Education program consider Padlet to be something new to them. They have not found and seen it before this research was held.

Coming to the main discussion of this research, respondents were asked about their perceptions on using Padlet in the learning of Introduction to Functional Linguistics. Their responses then are as the following (in Bahasa).

\section{Menarik (3)}

Membantu dalam pembelajaran (2)

Bagus untuk diskusi bersama

Sangat membantu

Menyenangkan, Tetapi kendalanya adalah ketika jaringan buruk.

Menarik. Menurut saya penggunaan padlet tidak hanya dapat meningkatkan kreatifitas tetapi kami dapa menuangkan gagasan secara bebas dan kami juga bisa berdiskusi tentang materi yang telah kita pelajar bersama.

Menurut saya penggunaan padlet dalam pengajaran sangat baik. Karena ini adalah salah satu bentuk pengajaran baru dengan memanfaatkan sebuah media dalam pembelajaran.

Sangaaat menarik

Sangat bagus
Menarik, memudahkan

Bermanfaat

Sangat membantu dan menyenangkan

Saya pikir itu sudah cukup bagus

Efektif untuk menambah pemahaman

Mudah dan bermanfaat, sangat membantu untuk berbagi gagasan yang berbeda

Cukup menarik

Menyenangkan karena mudah menggunakannya

Kurang efektif

Sangat efektif karena mahasiswa dapat mengirimkan tugas lewat padlet tanpa harus bertatap muka

Sangat Bagus, karna mengasah cara fikir kita tentang materi dan membuat kita untuk membuat inovasi.

Menarik kurang lebihnya

Cukup membantu

Cukup menarik. Karena mahasiswa bisa bertukar dan berbagi ide dengan yang lain.

Sangat membantu. Selain membuat kegiatan belajar menarik juga membantu untuk memotivasi belajar

Picture 3. Students' Perceptions of Using Padlet in Introduction to Functional Linguistics Class

Data from figure 3 stated that most students answer with short answers, such as the following: interesting, useful, fun, good, good, enough and very helpful. Some of them answered in more detail. According to them, the use of padlets not only can increase creativity but they can also pour ideas freely and can discuss material that they have learned together. In short, after using Padlet in classroom learning Introduction to Functional Linguistics, they have the perception that learning on the subject becomes effective.

Only a small percentage of them (1 respondent or $3.5 \%$ of all respondents) said that the use of Padlet in the learning and teaching process was less effective. One other respondent mentioned that there were obstacles found in the implementation, namely when the internet network was bad. When the internet network is bad, Padlet cannot run properly. Therefore, a good internet network is absolutely necessary in its implementation.

From the data obtained through the questionnaire, researchers can conclude that the actual use of Padlet media in learning Introduction to Functional Linguistics is very effective in helping to improve students' understanding of the course. After all, the implementation will run very well if supported by good internet network facilities.

Most students (78\%) stated that they were happy when class learning Introduction to Functional Linguistics used Padlet media. Only very few of them $(5 \%)$ openly expressed their displeasure. The rest says "maybe". That is, the use of this media becomes 
something different for students compared to other classes.

Students did not encounter significant difficulties in using Padlet during learning both in class and outside the classroom. It is understandable that all students are now literate with the use of technology in learning.

In addition, almost all students saw that the Padlet's appearance was interesting. They like the features available. When being asked about whether they can convey their own ideas on the materials of linguistics, most students stated that they felt that they were able to submit ideas related to the material in the course Introduction to Functional Linguistics. Ideas that are buried can be poured freely on the walls of the Padlet media. Moreover, they claimed that the use of Padlet in the class Introduction to Functional Linguistics can make it easier for them to better understand the material.

In its implementation, lecturers often held discussions with students by using Padlet. The data taken from the students' responses showed that most of them like the method. It is just that maybe the lecturer needs to be more creative in the implementation process. Because, after all, something similar that is used repeatedly will certainly bring boredom to some students. Therefore, lecturers' creativity and intelligence are needed in managing this kind of class. In last, most of students assume that the use of Padlet can improve linguistic skills such as speaking skills, listening, writing, and reading.

\section{CONCLUSION}

From the data obtained through questionnaires distributed to 28 students of the English Language Education Study Program at the Faculty of Languages and Communication of Sultan Agung Islamic University Semarang in the class of 2014/2015, researchers can conclude that these students have very diverse perceptions in the use of Padlet media in learning Introduction to Functional Linguistics. To be sure, most students really positively appreciate the use of this media in linguistic learning in general.

More specifically, most of the students thought that Padlet was something new to them. They stated that they were happy when learning class Introduction to Functional Linguistics using Padlet. They also have no significant difficulties in using the media during learning both in the classroom and outside the classroom. In addition, they see that the Padlet display is interesting with the features available. After all, they feel facilitated to be able to express ideas related to the material in the course Introduction to Functional Linguistics. They stated that the use of Padlet in the class Introduction to Functional Linguistics can make it easier for them to better understand the material properly. As a result, the implementation will run very well if supported by good internet network facilities. We recommend that this kind of research be developed in classes in other subjects to test whether the use of Padlet media is effective for all types of classes.

\section{ACKNOWLEDGEMENT}

In the end, the researchers would like express gratitude and acknowledgment to those who have helped us finishing this kind of disseminate article for some betterments, they are the department of research and community services (LPPM) and teaching staffs as well as the dean of language and communication faculty of Sultan Agung Islamic University.

\section{REFERENCES}

[1] Jaganathan, S. 2016. Edmodo and Padlet as A Collaborate Online Tool in Enriching Writing Skills in Language Learning and Teaching. Available at: https://www.researchgate.net/publication/3024 72966_Edmodo_and_Padlet_as_a_collaborative_ online_tool_in_Enriching_Writing_Skills_in_Lan guage_Learning_and_Teaching (accesed on May 09, 2016)

[2] Kaya, H. (2015). Blending Technology with Constructivism: Implication for an ELT Classroom. Teaching English with Technology. v15 n1 p3-13.

[3] Weller, A. (2013) 'The use of Web 2.0 technology for pre-service teacher learning in science education', Research in Teacher Education, 3(2), pp. 40-46.

[4] Fuchs, B. (2014). The writing is on the wall: Using padlet for whole-class engagement. Kentucky: University of Kentucky.

[5] Mallon, M. and Bernsten, S. (2015). Collaborative learning technologies. USA: Association of College and Research Libraries and American Library Association. 
[6] Deni, A. and Zainal, Z. I. (2015). Let's Write on the Wall: Virtual Collaborative Learning Using Padlet. Available at:

https://www.researchgate.net/publication/2919 72839.

[7] Lestari, S. (2016). Implementing Padlet Application to Improve Writing Ability in English Writing Skill for Non English Department Students. LET: Linguistics, Literature and English Teaching Journal Vol. 7. Available online at: jurnal.uin-antasari.ac.id/index.php/let.

[8] Haris, M., Yunus, M. M., and Badusah, J. H. (2017). The Effectiveness of Using Padlet in ESL Classroom. International Journal of Advanced Research (IJAR). http://dx.doi.org/10.21474/IJAR01/3214.

[9] Best. (1981). Research in education. New Jersey: Prentice Hall Inc.

[10] Dörnyei, Z. (2007). Research methods in applied linguistic. Oxford: Oxford University Press.

[11] Crossman, A. (2017). Convenience sample: A brief overview of the sampling technique. https://www.thoughtco.com/conveniencesampling-3026726. Accessed on 2 March 2017.

[12] http://www.padlet.com.

[13] Arikunto, S. 1998. Prosedur Penelitian: Suatu Pendekatan Praktik. Jakarta: PT. Rineka Cipta. 